\title{
Pattern of Buginese Ethnic Family Communication in an Effort to Maintain The Sustainability of Cocoa Farmers Children Regeneration in South Sulawesi
}

\author{
Tuti Bahfiarti \\ Departement of Communication \\ Faculty Social and Political Science \\ Hasanuddin University \\ Makassar, Indonesia \\ tutibahfiarti@unhas.ac.id
}

\begin{abstract}
Indonesia is the third largest cocoa producer in the world, especially in Sulawesi corridor. Regeneration of cocoa farmer's children needs more attention to keep the sustainability of cocoa production. This apprehensive situation when cocoa farmer's children which most of them are Buginese Ethnic cannot survive and doesn't have any interest to become cocoa farmer. This condition cause cocoa farmer's children prefer to work in informal sectors or planting other type of commodity besides cocoa. Family communication approach based on Buginese ethnic local is important point to minimalize crisis of cocoa farmer regeneration in South Sulawesi. Research method uses qualitative descriptive approach by exploring family communication studies of Buginese Ethnic deeply which still engage with local values. The selection of informant uses purposive sampling technic which select 9 Buginese Ethnic families who have 6-15 years old child. Primary data is collected through non-participant observation and indepth interview to farmer groups including Sinar Cendana 1, Sinar Cendana 2, and Sinar Cendana 3 in East Timur Regency Province of South Sulawesi. This research result shows that pattern of buginese ethnic communication family is covered; first, dialogical orientation pattern: focus on problem solving communication, interactively between family members, does'nt focus to parents in finding alternative problem solving of cocoa farmer's children regeneration. Parties, both children and parents interact actively in cocoa production processes. Second, control orientation pattern: focus on parent's ability as leader in family to provide alternative solution of problem solving. Leader takes a role and dominant position and then children obey the family decision. Family communication arouses and motivates less active children to become cocoa farmer. This research result contribute to provide role model of buginese ethnic family communication development in internalize local values to minimalize crisis of cocoa farmer regeneration in South Sulawesi.
\end{abstract}

Keywords-family communication; cocoa farmer regeneration; South Sulawesi

\section{INTRODUCTION}

Cocoa is one of the third largest contributors for Indonesia's income after palm oil and rubber with revenues
USD 1,8 Billion or increased $20 \%$ if comparing to the previous day (bisnis.com, 2009). Cocoa has important roles for the national economic growth, especially in providing employment, national revenue and foreign incomes. Cocoa plantation has been become the largest foreign revenue in South Sulawesi Cocoa Plantation Center. Referred to that argument, nowadays sustainability of cocoa become world's attention.

Cocoa productivity decrease are caused by pest, plant diseases, cocoa tree age, and switch to other commodity and also urbanization, many of farmers rethink to continue produce cocoa. On one side, that challenge cause lower productivity and income for the farmers. Average age of cocoa farmers is about 50 years old so that can minimalize number of active farmers, and it cause there is an impression coca sector not attractive for the young generation, especially cocoa famer's children.

Inadequate of young generation who attracted to work in cocoa sector cause the cocoa regeneration needs to get more attention to sustain the cocoa production sustainability, especially in South Sulawesi's cocoa plantation center. Cocoa regeneration crisis can be minimalized by giving priority scale based on child composition in cocoa farmer family, where average two to four child of each family is prepared as cocoa family farmers' regeneration. Great potential can be optimized to rebuild the sustainability of cocoa farmer's children.

Family environment is the earliest and dominant environment in internalize and develop interest to become cocoa farmer. Family communication is central effort for cocoa farmer's children regeneration in forming effective interpersonal communication. Level of emotional proximity between parent and child become focus to enhance love to the cocoa.

Family communication can be started from parents by educate, habituate, stimulate and motivate child to fond and love cocoa as source of life. It is important to defended and improved because fond and love to cocoa is skill that obtained after someone born and interacted with their environment, not inherent. Family play important role in conserving norms to 
the child, one of that is local wisdom. Norms of local wisdom is guideline for men and women to act based on community consensus. This is important to be inherited and educated to children in their early age in order to get enough knowledge to form character in the future. In this phase parents role important to give an understanding about local wisdom norms to the children.

This research focus is pattern of family communication which is developed in internalize children love to the cocoa plantation. Based on theoretical framework that family communication as a part of interpersonal communication which can foster norms continuously. The differentiation to the previous research entitle Communication Pattern of Malay Families in Terengganu [1]. Malaysia focused on parent and child communication pattern. Children become primary respondent, while parent become secondary respondent. There was two types pattern that is emphasized on conversation orientation and suitability orientation. This research involved 1.012 respondents in Trengganu, Malaysia by using quantitative method to process the data. The result showed that respondent use both form of communication in the medium level and that communication can explain relation between family members.

The success of your family relationships depends heavily on the interpersonal communication among members [2]. Forms of interpersonal communication effectiveness among others: first, interpersonal communication is openness. Openness is a reaction to the disclosure or our response to the present situation and provides information openly. Hidayat cites the opinion of Emmert and Brooks that the characteristics of the person who has an openness is assessing the message objectively, using data, seek information from various sources, and seek to understand the message that does not comply with a series of beliefs.

Second, empathy (empathy) to feel what others feel. Interpersonal communication able to takes place with the condition when the communicator (the sender) show empathy to the communicant (recipient of the message). Third, the characteristic of support (supportiveness) is openly situation to support the effective communication. Fourth, positive (positiveness) is the tendency of a person to be able to act based on positive judgment without excessive guilty feeling, accept their self as an important and valuable person to others, have confidence on their own ability to address the issues, sensitive to the needs of others, on social customs that have been received. Fifth, is the equality or similarity (equality) is recognition among two parties to respect each other, useful, and has something important to contribute [3].

Cocoa regeneration in farmers' children is important to get more attention in order to maintain level of cocoa production sustainability especially in cocoa plantation centre in South Sulawesi. It's cannot be imagined if cocoa farmers children have no intention anymore to become cocoa farmer or everything related to cocoa plantation. These research focuses are; first, categorize and analyze family communication pattern which is applied in Bugis Ethnic in nurturing and educate children in family. And also internalizing of local wisdom norms since early stage of children so they have an intention to continue parent job in cocoa plantation especially in South Sulawesi's cocoa plantation center.

\section{RESEARCH METHOD}

Data analysis use Miles and Huberman qualitative data analysis, in form of words, sentences or narrations, from indepth interview or observation [4]. Source of data is consisted of primary and secondary. Primary data is collected from the informant trough in-depth interview, and non participant observation. This research observes 9 Bugis ethnic families who rely their life on cocoa plantation sector.

Informant selection technic by purposive sampling, based on criteria that is previously determined. Purposive sampling can be categorized as judgmental sampling, because researcher determine subject feasibilities to select as sample. Character has been determined intentionally including, first, Bugis Ethnic cocoa farmer family both from father or motherside. Second, having 7-15 years old son or daughter. Third, parents and child living together as core of the family. Fourth, applied local wisdom norms in educating their child. Fifth, give priority to education concept based on their cultural identity. While informant from child, first, 7-15 years old boys/girls from bugis ethnic family both from mother or father-side. Second, children who living together with their parents as core of the family. Third, cocoa farmer's children who educated with local wisdom norms. Fourth, Bugis ethnic cocoa famer's children that their parents applied education concept based on their cultural identity.

This research location is in Cendana Village as cocoa plantation center in Luwu Timur Regency, South Sulawesi Province. This research focus on farmer groups named Sinar Cendana 1, Sinar Cendana 2, and Sinar Cendana 3 which source of their income is in cocoa plantation.

Activity in data analysis are data reduction such as; select basic information, focus on important thing, looking for the theme and pattern, data display, chart, relation between category, flowchart, and conclusion drawing/verification. Initial conclusion which stated is temporally, and can be changed if supporting evidence is not found in the next phase of data collection.

\section{RESULT AND DISCUSSION}

This research informant are Bugis ethnic cocoa farmer families including father, mother, son and daughter. Their parents work as cocoa farmer hereditary. Characteristic of selected informant is cocoa farmer family whose parent involves son and daughter directly to participate in cocoa plantation. Head of family based on age, 25-35 years old as many as 5 people, and 36-45 years old are 4 people who have 7-15 years old child. 


\section{A. Family Communication Pattern of Bugis Ethnic}

Communication process between parent and child is important factor in local wisdom norms inheritance to the child. Child learns to understand communication messages trough interaction with parent. Parent and child act as communicator and communicant. For example, child gets information including manners of behave and also how to grow cocoa. Child response to local wisdom norms inheritance trough interpersonal communication can be seen from mindset, manners, and how they interact with people in their environment.

This research find from nine bugis ethnic families that observed show that parent involve their son or daughter in cocoa planting processes since nurseries to harvest. Research result find that there are two types of coca farmer families applied, Dialogical Orientation Pattern and Control Orientation Pattern, like the following Table 1:

TABLE I. FAMILY COMMUNICATION PATTERN OF BUGIS ETHNIC

\begin{tabular}{|c|c|c|}
\hline $\begin{array}{c}\text { Informan } \\
\text { Cocoa } \\
\begin{array}{c}\text { Farmer's } \\
\text { Children }\end{array}\end{array}$ & $\begin{array}{c}\text { Family Communication } \\
\text { Dialogical Orientation } \\
\text { Pattern }\end{array}$ & $\begin{array}{c}\text { Control Orientation } \\
\text { Pattern }\end{array}$ \\
\hline Family 1 & $\sqrt{ }$ & \\
\hline Family 2 & $\sqrt{ }$ & $\sqrt{ }$ \\
\hline Family 3 & $\sqrt{ }$ & \\
\hline Family 4 & $\sqrt{ }$ & \\
\hline Family 5 & $\sqrt{ }$ & \\
\hline Family 6 & $\sqrt{ }$ & $\sqrt{ }$ \\
\hline Family 7 & $\sqrt{ }$ & \\
\hline Family 8 & & \\
\hline Family 9 & & \\
\hline
\end{tabular}

Source: Primary Data Processed, 2018

This research find that pattern that applied by parents to inherit local wisdom norms categorized into two types, Dialogical Orientation Pattern and Control Orientation Pattern. Pattern that applied by parent to their child bring effects to children messages reception because they can be categorized as kid and adolescents. Parent's dialogical orientation pattern communicate norms to children by two ways interaction, that means children actively involved in transactional communication, like following picture:

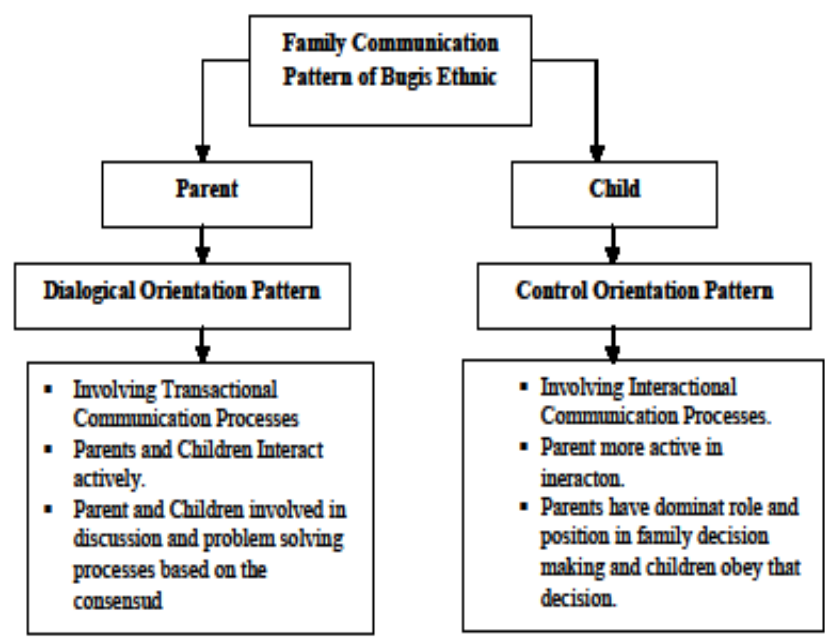

Fig. 1. Family Communication Pattern of Bugis ethnic Source : Primary Data Processed, 2018

Dialogical orientation pattern focus on communication to solve problem, interactively inter family member, not focus on parents in finding alternative problem solving about cocoa farmer children regeneration. Parties, parents and children actively interact in the processes of cocoa production. In dialogical orientation pattern transactional communication process, there is meaning consensual between parents and children. Next, control orientation pattern focus on parent's ability as leader in family to provide alternative solution of problem solving. Leader takes dominant role and position, and children obey the family decision. Family communication pattern goals are to waken arouse and motivate inactive children to become cocoa farmer.

\section{CONCLUSION}

This research finds that dialogical orientation pattern transactionally involving meaning change so that parent and children can maximally interact. This pattern focus on parent and children to find alternative problem solving about cocoa farmer's children regeneration. Next, control orientation pattern interactionally focus on parent's ability as leader and dominant position while children obey the family decisions.

This research recommendation is ggovernment, Profit Organization, and Non-Profit Organization need to improve the communication pattern with dialogical orientation. Because family is the smallest environment to fostering love to the cocoa. In the long-term can minimalize cocoa farmer's children regeneration crisis that really apprehensive. Sustainable program become alternative solution to enhance cocoa productivity. 


\section{ACKNOWLEDGMENT}

We would like to thank the Kemenristek DIKTI through the Competency Grant (HIKOM) and LP2M Unhas for trust and funding in 2018. Thank for trust to develop interpersonal communication studies. Thanks also the author dedicated to cocoa farming families were very supportive of this research. Aswin Baharuddin and Amal Darmawan as a team of enumerators who have contributed in the implementation of research.

\section{REFERENCES}

[1] C. H. C. Noh, F. Yusooff, M. S. Hasim, “Communication patterns of Malay families in Terengganu, Malaysia,” Procedia-Soc. and Behav. Sci., vol. 102, pp. 635 - 642, 2012.

[2] J. A. Devito, The Interpersonal Communication Book. 9th ed. New York: Longman, 2001.

[3] D. Hidayat, Komunikasi Antarpribadi dan Medianya [Interpersonal Communication and its Medium]. Yogyakarta: Graha Ilmu, 2012.

[4] M. B. Miles, M. Huberman, and J. Saldana, Qualitative Data Analysis: A Methods sourcebook. Los Angeles: SAGE Publications, 2014. 
